\title{
The Indian zebu in Brazilian lands
}

\author{
JoANA MEDRAdo
}

\section{KEYWORDS: Brazilian rural history, cattle breeding, racial stan- dardization, Indian zebu.}

\author{
JEL CODES: N0, N56, O30, Q16.
}

I 7 this article we will examine the history of Brazilian cattle breeding in the early twentieth century, focusing on the transitional period of intensification of production, when the racial standardization of cattle began to be considered key to industrializing breeding practices. To this end, we consider the initiatives of a group of farmers from the far east of Minas Gerais (Mineiro Triangle), who travelled to Northern India between 1913 and 1917 to acquire bulls and cows of the zebu breed. Retracing the routes of their voyages to India thanks to the diaries and letters between these farmers in Brazil and India, we attempt to understand the role that Indian bovine cattle played in Brazil. The first farmers to make this trip moved in the sphere of the influential elites of the oligarchic Republic that was established in Brazil in 1889. This article argues that these farmers were driven by diverse factors, which could not be reduced to the single issue of an increase in economic productivity. In truth, there were political interests mainly related to the strengthening of personal prestige and the construction of a class character as "innovative cattle farmers" in a context of intra-oligarchic disputes over exerting influence in the Republican state. 


\section{$\mathrm{O}$ zebu indiano em terras brasileiras}

\section{PALAVRAS-CHAVE: história rural, história do Brasil, pecuária, pa- dronização racial, zebu indiano.}

\section{CÓDIGOS JEL: N0, N56, O30, Q16.}

$\mathcal{} \begin{aligned} & \text { este artigo iremos analisar parte da História da Pecuária Brasileira do co- } \\ & \text { meço do século } X X \text {, focando no periodo de transição para a intensificação pro- } \\ & \text { dutiva quando a padronização do rebanho bovino começou a ser considerada }\end{aligned}$ a chave do processo de industrialização da produção. Para tanto, vamos investigar a iniciativa de um grupo de fazendeiros do extremo oeste de Minas Gerais (Triângulo Mineiro) que pessoalmente foram ao norte da Índia entre 1913 e 1971 para adquirir reprodutores das raças zebu, registrando suas trajetórias de viagem em diários e cartas trocadas entre os fazendeiros no Brasil e na Índia. Nesse sentido, tentaremos entender o papel que o zebu desempenhou no Brasil. Esses primeiros fazendeiros que foram à Índia orbitavam muito próximo às elites influentes na República Oligárquica, instaurada no Brasil em 1889. O argumento que se pretende tecer neste artigo é que os fazendeiros que trouxeram o zebu da Índia eram movidos por diversos interesses que não podem ser reduzidos ao aumento da produtividade econômica. Na verdade, havia interesses politicos precipuamente relacionados ao fortalecimento do prestígio pessoal e da construção de um atribuo de classe enquanto «vanguarda pecuarista» em um contexto de disputas intraoligárquicas para manter certa influência no Estado republicano.

Joana Medrado is professor at the department of history of the Universidade Federal do Reconcavo of Bahia. Address: UFRB, Campus de Cachoeira, R. Mestro Irineu Sacramento, s/n, Centro, Cachoeira, BA, 44300-000 (Brasil).E-mail:joanamedrado@gmail.com 


\section{INTRODUCTION}

Bovine cattle were foreign to Brazilian fauna. It was the European expansion of the $16^{\text {th }}$ century that brought European quadropeds to America as another type of colonizer, according to the suggestive interpretation of Alfred Crosby (1993: 160). The region of the pampas, which stretches between the countries of the South Zone, was the most amenable to European animals, owing to a similar climate. It was there that cattle spread more quickly, reproducing naturally and defining much of the agrarian character of the social and economic relations. Brazil's climatic diversity however (predominantly tropical) did not act as a limit for cattle farming, and it was not just in the "neo-Europe" of the country's south, that bovine cattle flourished. The cattle spread throughout all climates, terrains, and landscapes, presenting, therefore, different challenges for cattle farmers. In this article, we will consider part of the history of cattle breeding, especially during the transitional period toward intensification of production, in an attempt to understand the role that Indian bovine cattle (zebu) played in Brazil.

\section{FROM PASTURES TO CATTLE GRAZING: CATTLE TRAILS IN BRAZIL}

At the end of the $19^{\text {th }}$ century, some farmers expressed particular interest in the "modernization" of grazing practices in Brazil. It was a context of progressive urbanization, when the population of the Brazilian southeast went from 7 million to 22 million people between 1900 and 1950, as Warren Dean highlighted in his classive $A$ Ferro e Fogo. Dean, by conceiving of this period as predatory industrialism also argues that the needs for primary and secondary forests justified the devastation of the forests. On the other hand, there was also an expectation of a boom in international demand for this food, which in fact took place during the First World War. From this perspective, the Brazilian farmers relied on certain strategies to increase meat production, taking as a model neighboring and prosperous Argentina.

When the First World War overtook Europe, there was a strong impact on meat production in Brazil. Firstly, due to the War, European production decreased owing to the disorganization of production. Secondly, strong market suppliers in America and Argentina had already reached their productivity peaks, and were not able to increase supply commensurate with growing demand. Additionally, it is worth noting that growing demand in Europe was also driven by a stimulus of consumption based on the spread of positive ideas regarding the nutritional value of meat. The production and consumption of animal protein was stimulated at that time as a food fundamental to maintain men strong and virile for business and war, and, equally important, so as not to complain about 
the arduous work in factories. In articles such as "The frozen meat industry in the Argentinian Republic" the innovative consumption of frozen meat on the part of the English (since the 1880's) and the cheapening of the product, which made it a question of primary necessity amongst British agents, while remaining a luxury item on the continent, can be observed.

Accompanying these tendencies, the Brazilian zoologist, Joaquim Carlos Travassos, when writing his Agricultural Monographs, reached the point of speaking of a Primordial God, who would supposedly be the confirmation that humans had needed animal protein to change size and form. That is to say, there was a discursive effort to popularize and normalize the consumption of meat, a practice, which not even the scientific manuals managed to defend.

In Brazil, parallel to this process, changes and increases in production, which led cattle farming to lose some of the colonial characteristics that tied it to so called pastoralism, so as to assume a place in the national economy as cattle grazing (a term adopted during this period to define the activity of cultivation on a "modern farm") were being promoted. Together with other elements, such as the cultivation of new food for the growth and fencing of pastures, the "racial improvement" of bovine stock gradually came to be considered the main issue to increase production. As the renowed zoologist Fernand Ruffer said in 1917: The whole question, for the Brazilian cattle farmer, consists in substituting, without damage, their varied, polymorphous, and multicolored stock, with cattle with uniform colour, size, shape, weight, yield, and practical characteristics ${ }^{1}$.

In this way, the racial standardization of cattle became key to industrializing breeding activity. Far from being straightforward however, there was a concerted effort necessary to attain this standardization leading to many doubts in this regard, especially in Brazil, where there was little formal zoological knwoledge. Given this, the alternative for importation of reproducers and subsequent selection seemed to be the most reliable way to carry out this project, as one deputy already indicated in a session of the Assembly in 1884:

The Brazilian races still find themselves in a primitive state, and it is impossible, in one go, to transform them into perfect animals. It would be preferable to introduce into the country, repoducing animals, which already possess the forms and previously indicated aptitudes, and with them realize crossings, whose outcome could

1. Fernand RUFFIER (1917). Ways of improving the national races. Thesis n. 12, National Grazing Conference, Rio de Janeiro, p. 61. IHGB-206, 7, 2, n. 40. 
be rigorously subordinated to the laws of selection; perfecting them later by the introduction of pure blood, to achieve the race that one wished to obtain ${ }^{2}$.

The deputy continued his presentation, pointing out that each region should select the races according to their productive profile, be it milk, meat, transportation, or leather. If, on one hand, this idea was not new amongst modern agricultural breeders, who had already, since the end of the $18^{\text {th }}$ century affirmed that rural economies could only be "improved" through specilaization of production, on the other hand, the qualitative change in this discourse is well known. The deputy's presentation proposed that the path toward modernization, defended by the rural elites of the $19^{\text {th }}$ century, was principally via genetically "perfecting" the animals, through the selection of national races and the importation of foreign reproducers with the desired characteristics, both alternatives based on the theories of Darwin.

Was it possible however, to determine the origins of this process of intensification of production in addition to strictly economic factors? Moving through the history of the agronomical sicences, studying Brazilian agronomy between 1808 and 1889, Eulália Lobo (1980) investigated how throughout the $19^{\text {th }}$ century, farms and botanical gardens played a fundamental role in the development of the agronomic sciences and in the realization of this process of modernization based in the perfection of species. In the words of the author, it was mainly due to farms and botanical gardens, as well as to the adoption of experimental pastures, and the circulation of agronomic knowledge (Lobo, 1980: 25). Proof of this were the activities undertaken in the institutions created with this aim at the time, such as the Botanical Gardens of Bahia, founded on the $3^{\text {rd }}$ of March, 1800, the Royal Botanical Gardens of Rodrigo de Freitas Lake, the Botanical Gardens of the Public Walk, Olinda Gardens, the Recife Spice Gardens, Minas Gerais Plant Garden, the Botanical Gardens of Cuiabá, and the Plant Garden of Bahia. It also included courses in Bahia, instituted on the $25^{\text {th }}$ of July, 1812, and the Practical and Theoretical Agronomic College at the Royal Botanical Gardens of the Rodrigo de Freitas Lake, founded in 1838. Even the Auxiliary Society of National Industry, founded on the 31 ernmental support and also promoted the importation, aclimatization, research, and distribution of plants; it gave prizes not only to whoever developed new cultivars, but also to those who introduced and invented machines. Its other functions involved the purchasing and distribution of machines at cost price (Id.).

In addition to these institutions, European travellers and interested Brazilian parties circulated knowledge of the second agricultural revolution, which had taken place in Eu-

2. Report of the session of the 25 legislature, on the 1st of August, 1884. Arquivo Público Mineiro. 
rope and, in this way, contributed to the establishment of the idea that there was a need to "save" farmers from what they called the brutal routine, and ignorance in dealing with the land. Following this line of argument, João Fragoso (1986) wrote an article about the modernization proposals for Brazilian agriculture in the $19^{\text {th }}$ century and noted that men of science of the $19^{\text {th }}$ century were dedicated to spreading agronomical know-how and technology developed in Europe, to overcome (rather than accept) climatic challenges specific to that continent. Contrasting himself to this, Fragoso, using the agronomic engineer Ana Primavesi, argued that agronomical technology would be an ecotype, that is to say, something far from being accepted in the $19^{\text {th }}$ century, but that should be taken into consideration by certain farmers, especially producers of zebu cattle, as will be considered throughout this article. Generally, throughout this period the importation from Europe of machinary, tools, botanical species, and animals, as well as knowledge regarding epidemics and diseases and their treatments, was stimulated. According to this tendency, the paradigm of rural modernization would serve as a reference for the old colonial Americas, as a storehouse for food resources to be exploited by the imperialist powers at that time.

During the republican period, however, already at the beginning of the $20^{\text {th }}$ century, other modernization dynamics emerged. Though still based on the European paradigm, the improvement and aclimatization of exogenous and native races and species no longer took place only in an experimental fashion, with a strict scientific foundation in institutional contexts such as in botanical gardens and zoos. At the beginning of the $20^{\text {th }}$ century, the scenario for this modernization became, mainly, private with "model" farms supported by the government for economic and industrial aims. These farms served as staging points (for animal crossing) and stores for reproducers (bulls and females). It was science subsidised by the government and applied to pastoral industry.

\section{THE ZEBU AND ZEBOCULTURE: ORIENTALIZING AND TROPICALIZING THE ZOO-TECHNICAL DEBATE}

It is evident that within the scope of this article, it will not be possible to consider all the aspects of the production increases in Brazilian grazing. Some selections therefore, will be made. Of these, the main one is is to attempt to understand specifically why the zebu presented such success in the projects of racial standardization, and who were the breeders and enthusiasts. With this in mind, in this article, we will consider the initiatives of a group of farmers from the extreme east of Minas Gerais, (Mineiro Triangle) who personally went, for the first time, to Northern India to acquire zebu bulls and females. In 1918, this group created the Herd Book Zebu Foundation, which retained the exclusive 
rights for genealogical registering of zebu races throughout Brazil and from that time became influential ruralists.

The origins of the Indian zebu in Brazil go back to an under developed period in Brazil during the $19^{\text {th }}$ century, about which we will not go into too much detail owing to our already having done so in other studies (Medrado, 2013). It is important however, to emphasize that the zebu in the $19^{\text {th }}$ century was seen as an exotic animal, to understand how it fit into the collective, experimental, and scientific imaginary of the epoch. Therefore, it was not an animal for use in industrial grazing, as we noted above, based on the study by Eulália Lobo.

Therefore, the reports of voyages made to India to acquire bovine reproducers, show that a strain of orientalism in Brazil occured in fairly unexpected ways. During the illustrious reign of the Second Emperor (1840-1889), farmers from the Mineiro Triangle, inheritors of the $19^{\text {th }}$ century, particularly the second half, became interested in India. They were attracted not by its spices, exotic dances, philosophy or folklore, but rather by the quality of its bovine cattle, motivated to "improve" the "rustic" cultivation of cattle practiced until then in Brazil, seeking to transform this breeding into a truly industrial and $n a-$ tional practice.

Belonging to the subspecies Bos indicus, and therefore different from the Bos taurus of European origin, zebu was an animal that circulated around the zoological gardens of Europe, sharing space with the dromaderies, owing to their physical similarities: the hump of the dromadery and the forehead of the zebu. Therefore, they were animals sold by firms specializing in exotic animals, which supplied zoos and circuses all over the world. The most significant example of this was the famous Hagenbeck Firm, of Carl Hagenbeck, based in Hamburg and recognized in Europe for dealing with this market, bringing around 200 zebus to Brazil between 1800 and 1805. However, on arriving in Brazil, these animals were destined much less for exhibitions and more frequently for cattle farmers, who were already interested in zebu as reproducers for cattle breeding.

However, beyond these importations by the Hagenbeck firm, fundamental for the introduction of zebu into Brazil, we consider that the first cycle of importations of Indian reproducers by Brazilian breeders specifically for breeding purposes began in fact in 1898, when the first voyage by a Brazilian to India, Teófilo de Godoy, with this specific aim, took place. This continued until 1921 when the Brazilian government prohibited the importation of Indian bulls and females into the country alleging health reasons. This was almost certainly motivated however by a decree from England, which was the largest importer of Brazilian meat, which had blocked the entry of frozen meat from Brazil into 
Europe through English ports, because the meat was considered highly "zebuized". After almost ten years of prohibition of zebu in Brazil, some importations were allowed in 1930 and other "missions" to India occurred in 1952, 1959, 1960, and the last in 1962, when the entry of zebu into Brazil was once again prohibited. This did not prevent illegal importation however. Therefore the 6,000 zebu officially imported during this period (and many others illegally) were the origin in Brazil of more than 190 million animals, which meant that zebu blood today accounts for around $80 \%$ of the national stock.

These first farmers who went to India were land owners but did not have a grazing tradition. They were particularly connected to trading and investment in land, as a strategy for security of property. They moved in the sphere of the influential elites in the oligarchical Republic established in Brazil in 1889, but did not however, benefit form this proximity. To the contrary, they were excluded in the first decades from the benefits received by coffee growers and milk producers who were the political protagonists of the first Republic. Therefore, our argument in this article is that the farmers who brought zebu from India aimed not so much to improve the stock in itself, but rather to improve their own status: that of their political standing in negotiations with the government, and of their social legitimacy amongst landowners. In other words, the impulse towards zootechnical innovation that made them a Schumpeterian example in the cattle breeding avant-garde, to use the expression and interpretative model of Carmem Sesto (2000), had the aim of giving them access to the restricted world of privilege of the newly republican Brazil.

Given this, and attempting to consider these questions more closely, we will seek to follow some of the trajectories of the voyages to India based on the diaries and letters exchanged between these negotiating farmers in Brazil and India ${ }^{3}$. Logistical aspects of animal transportation between countries, the need for secrecy in the operations in India, and the political negotiations with the Brazilian government, and the definition (or invention) of the "ideal" racial characterisitics of the imported animals, will all be considered. Following this, we will attempt to elaborate some reflections regarding the relationship of these farmers with the Brazilian republican politics.

\subsection{The way to India}

In 1904, an importation firm for merchants and landowners was created in the city of Uberadba, in the Mineiro Triangle. It was named Borges \& Brothers, and was led by the Cor-

3. This correspondence is found in the Zebu Museum in the city of Uberaba. It is a private archive under the custodianship of the Brazilian Association of Zebu Breeders (BAZB). 
nel José Caetano Borges. Soon after its creation, the firm sent a Portuguese man, emigrated to Uberaba, Angelo Costa, to India, aquiring 49 reproducers for resale in Brazil. Successful in his business, Angelo Costa returned repeatedly to India, initiating an unexpected commercial practice in the era: photographing the imported animals before being sent to Brazil, so that they could be evaluated by potential buyers at animal exhibitions and commercial houses in Rio de Janeiro and Uberaba. Another foreigner emigrated to Uberaba, the Frenchman Alberto Parton was also driven by the excitement surrounding the importation of zebu, undertaking a number of trips to India for their importation. Another, to whom we encounter references in some letters, David Costa, was Portuguese and another resident of Uberaba. He was a priest in Goa but found himself in Buenos Aires in 1917 telegraphing the Brazilian consul in Calcutta, Joakim Nahapiet. He was, according to one message, certainly after cattle from the region for someone from Brazil ${ }^{4}$.

Given this, a preliminary question that stands out is the number of foreigners initially involved in the importation of zebu to Brazil. It could even be thought that Uberaba's international character, as a place bringing together many foreigners, had occassioned the realization of such an exotic idea for the time.

The year 1907 was an important moment in the consolidation of support in conjunction with the government with the aim of achieving a flow of public funds to make the importation of zebu viable. In the analysis of Lopes and Rezende, it was with João Pinheiro as the governor of the State of Minas Gerais that the First Cattle Exhibition took place in the State. Were it not for the political force of the cattle ranchers, combined with the "firm hand" of Pinheiro, zebu cattle would not have entered into the Exhibition pavillions (Silveira, 1917: 22). Pinheiro also stimulated and made official the importations of zebu cattle, allowing the entry of around 200 reproducers, in purchases made, in the greater part, through commercial importing houses Arens, Hoopkins, and Herm Sholtz (Lopes \& Rezende, 2001: 33).

In the interim between 1913 and 1917, three voyages to India by an important character in our story, João Martins Borges occurred, which we will be considering here, owing to their having been well documented in diaries and correspondence. João Martins Borges, born in 1890 on the Canoas farm in the municipality of Araxá, in the Mineiro Triangle, was one of ten children of Joaquim Martins Borges and Cornélia Candida de Oliveira Borges. His family was influential in the local, and he was also the nephew of José

4. Letter of João Martins Borges sent from Ahmedabad, to Joakim Nahapiet, on the $28^{\text {th }}$ of December, 1917, pp. 103, 104. From here on, the reference to the letters will omit the sender, owing to their all having been sent by João Martins Borges. 
Caetano Borges, founder of the firm Borges \& Brothers. His grandfarther, Joaquim Martins Borges, had been a rights judge of the county of the same name. For reasons little understood, João Martins Borges seemed the most precarious in the family hierarchy. To be able to ascend and distinguish himself within his society and family, he needed to expose himself more, risk more and leave the structures of familial comfort behind, and while still young adventure out on distant seas.

Before leaving Brazil, João Martins Borges distinguished himself as a trader, taking zebu from Minas Gerais to Rio Grande do Sul. However, his international journeying began when at 23 years of age he went to Europe, aboard the ship Principessa Mafalda with the objective of acquiring and reselling in Brazil a group of donkeys (asini) and 12 Turkish Burdizzos, a type of castrator for animals, which demonstrated his disposition and interest in the technological developments of cattle farming.

At the beginning of the following year, João Martins Borges departed on his first voyage to India, aboard the ship Andes. The First World War had still not commenced, and before it reached its end, João had already undertaken his third voyage, which would prove fatal, a man of fine bearing and still young, died in search of fortune in mysterious India, a biographer of his would say, dedicating a few lines to him (Nabut, 1975). This tragic event gave him his fame as a pioneering hero dedicated wholeheartedly to the cause of Indian cattle in Brazil. For the moment however, we will return to the start of his voyage.

The port of arrival for João's first voyage was Bombay, but the final destination was Ahmedabad, in the state of Gujarat, the right destination for those who came to deal in cattle. This was due to a prevalence of Muslims, where the cattle breeding is highly valued and carefully undertaken and the market is differentiated ${ }^{5}$. With the intention of acquiring between 60 to 100 head of cattle, João travelled to many places, which were cited in the letters: Radhanpur, Varsola, Harif, Pangli ${ }^{6}$. Crossing India from one tip to the other, from Bombay to Calcutta, he went, speaking with the right people, choosing his agents and facilitators for purchases and collecting information about the businesses of his competitors.

5. Letter sent to Calcutta, to Joakin Nahapiet, on the $15^{\text {th }}$ of December, 1917, p. 98.

6. Radhanpur and Varsola are cities still in the state of Gujarat; we did not identify where the city or village of Harif is; and Pangli, it is the tribe Jat in the state of Punjab in the Northeast of India and Pakistan. All these places are cited in a letter sent to Bombay, to João Carlos Salgado, on the $30^{\text {th }}$ of June, 1914. 
He had as a partner and investor in the enterprise, João Carlos Salgado, with whom the calculation of the cost of the shipping of 100 animals from India to Brazil, via Belgium, where the animals would be sent from the port of Antwerp and disembarked on the port of Santos, was made. The return however was hampered by the outbreak of the war. On the $30^{\text {th }}$ of September, 1914, Mr. Turner Morisson responded to João Martins Borges' letter, informing him of not being able to embark the cattle for Santos on the ships which went by the Prata river. The obstacle was confirmed by the British India Steam Navigation Company Limited, which in a letter to the partner João Martins Borges, said that due to the war, voyages for this company to Antwerp had been cancelled and therefore, the cattle could not be shipped.

Beside the difficulties in transporting the cattle, problems associated with arranging the local agents who facilitated the purchasing as well as understanding the culture and commercial ethics of the region were well known, especially during this first voyage. It was fundamental that João Martins Borges find the right men and surround himself with trustworthy people of confidence, taking care with people like the Mahometan who robbed him, disguised as a person by the name of Carvalho, an event about which João said that he didn't have a clue that he was betraying $\mathrm{me}^{7}$.

From the letters exchanged, one notices that soon on this first voyage, they discovered certain problems, which they attempted to resolve. They discovered, for instance, that the trick was to find agents from the same caste as the salespeople, paying beforehand and investing in the practice of repaying locals. Alerting one of his partners in India about the animals that he wanted to buy for his own breeding, João wrote: Do not forget to ask your men to find me two calves, for my own breeding, about which I already spoke with you. Whomsoever finds me good animals will receive good bokas, probably refering to Bakhshis, a type of Indian payment ${ }^{8}$.

Even with so many mishaps, João managed to buy 60 head of cattle, with a margin for more business, and there was no great difficulty in finding steamers to cross the ocean returning to Brazil, nor for the land transport in the internal stretches of India itself. The same war, which motivated the voyages in search of a bovine race that would "improve" national breeding stock, would evidently cause serious practical difficulties on this long voyage. On the $31^{\text {st }}$ of October, 1914, João desisted from taking the 60 head of cattle he had acquired, due to not being able to find a steamer from India to Brazil via Antwerp,

7. Letter sent from Bombay, to João Carlos Salgado, on the $1^{\text {st }}$ of August, 1914. According to the evaluation of the transcriber Ida Aranha, the date could have been the $8^{\text {th }}$ and not the $1^{\text {st }}$ of August.

8. Letter sent from Bombay to Nariman, on the $9^{\text {th }}$ of August, 1916, p. 54. 
nor by any other route. Having to return urgently to Brazil, João Martins Borges decided to leave the cattle in a government farm, the North Cote Cattle Breeding Farm, on the Charodi station, situated in the same city of Ahmedabad.

This farm was established between 1899 and 1900 with the intention of preserving and maintaining the breeding of the Kankrej race, which at the time combined the animals most sought after by Brazilian cattle farmers. According to the medical veterinarian Celso de Souza Meirelles (1944: 75), the Kankrej is a race

Natural to the area situated to the Southeast of the Rann region of Kutch and Ahmedabad. Additionally, it is breed on a large scale in the province of Bombay, to the West of Deesa, to the East of the State of Radhampur and particularly through the Banas and Sarasvalo rivers. Beyond the great region in the State of Baroda and Surat, and in the Kathiawar region. In the state of Radhampur it is known by the name of Wadhiar. This race is one of the most highly valued in India, not only for its strength and vigour in transport but also for being amongst the most sought after types. [...] Kangrej cattle was exported in great numbers to Brazil, having served for crossing to improve mixed race cattle. [...] Almost all the imported Guzerats, presented themselves as vestiges of the blood of this race ${ }^{9}$.

João returned for his second commercial enterprise in India in June, 1916, regardless of the ongoing war. This time he was accompanied by his brother Virmondes Martins Borges, Vulgo Candula, and his nephew, Otaviano Martins Borges, Tavico. He was also accompanied by his partner, João Caetano Borges, the leader of the firm Borges \& Brothers, previously mentioned. During this year, the great majority of the messages exchanged also spoke about the ships, freight for the transportation of animals, the possibility of making a trans-shipment in an intermediary port: Cabo City, Antwerp, Napels, Genoa, New Zealand, Montevideo..., there were many geographically dispersed alternatives. Everything was tried to deal with this situation, which seemed to be the most difficult step in the business, organizing the purchase of the cattle and transport. This was done to try to reduce the stay of the animals on the farms such as at Charoddi. This wait greatly increased the cost of the business, and even required the construction of corrals in the Indian countryside, something that was also found to have taken place (Lopes \& Rezende, 2001: 35).

9. Note that Guzerats, is a probable corruption or variation of the name Gujarat, the name of the main state in India from where cattle was imported, given that in the letters it is used to refer both to the place and to the type of cattle. 
Finally, they discovered the best option: send the cattle on ships, which took jute to Brazil. Ships, which left loaded with jute, and went directly from Calcutta to the port of Santos in São Paulo, still had space in the cargo hold to embark with the cattle in individual bays. Additionally, the facilitator of this step was the Brazilian consul in Calcutta himself: the Armenian Joaquim Nahpiet.

The scheme was clearly laid out in a letter sent to José Caetano who was in Brazil, in July, 1916, where he informed and instructed his partner:

The departure of the cattle now depends on the next load of jute and this depends on the request that they make from there; in this way, the Sr. should go to São Paulo and find, by any means necessary that the National fute Fabric Company makes, immediately, a request of Sr. Foaquim Nahaphiet, the consul here in Calcutta; as soon as the request arrives the jute will go and the cattle as well. Spare no effort because without the jute there will be no possiblity of steam ships going from here to Santos ${ }^{10}$.

In 1918, when he tried to return for his third voyage, he once again made use of the system of the jute steamboats and his contacts within the Brazilian consul, but this time already complaining about the mafia installed by the companies that began to load steamers and resell deck space at abusive prices. It was what the jute company had been doing:

The business of ensuring a place on all of the steamers, for them to later on sell it, at a price ten times more expensive, in plain Portuguese is called theft. The company, when it freights a steamer from the point of the mast to the bottom of the hold can make whatever use of it it best sees fit (...) but, when it only takes place for a certain quantity of jute, demands and negotiates the deck of the steamer, for them afterward to offer it at 10 times the price for which they contracted, it is simply theft ${ }^{11}$.

Additionally, one notes great care in the exchanges of messages to maintain their local contacts a secret. Such secrecy fulfilled at least two purposes: randomly define and legitamize the criteria for the identification of "good" racial characteristics for the cattle, and, monopolize the contacts and the local network of suppliers of the "best" animals.

Proof of this is a situation which occurred in 1914, when João Borges received the English farmer Sir Thobias Mello in Bombay, who was there in the company of Dr. Cyro Costa from São Paulo, interested in animals of the races Gir, Guzerat, and Kangreji. At

10. Letter sent from Calcutta, to José Caetano Borges, on the $24^{\text {th }}$ of July, 1916, p. 43.

11. Letter sent from Calcutta, to José Caetano Borges, on the $12^{\text {th }}$ of March, 1918, p. 113.

Historia Agraria, 75 • Agosto 2018 • pp. II $5^{-1} 3^{8}$ 
this moment, João Borges took advantage of the fact that the two were little informed about the subject and negotiated/offered "low quality" cattle, showing in one letter a clear effort to monopolize the contacts of cattle traders.

I want to entertain him, to buy Gir here [Bombay] with the aim of him not going to Ahmedabad, if not then only when he would select cattle from Sorab. His presence there can distract attention from our agents there [...] We need to take not only the beef cattle from Sorab to Sir Thobias but also the sick ox from here and the white one, and two more cows. In this way, our cattle will be correct, to the full extent of the word. We will also sell the two oxes that you bought from Abow. What does it matter! We will take little, but much ${ }^{12}$.

In the following letter, also addressed to his partner, he reiterates certain strategies. About the arrival of SirThobias Mello in Ahmedabad to buy the cattle from Sorab (one of their agents), João Martins Borges asks that his partner João Carlos Salgado convince Sorab to sell Sir Thobias the lowest quality cattle: As I saw that Tobias was already disposed to depart, I resolved to sell him the remaining cattle as soon as possible [...] Seeing Sorab's oxes, he would certainly buy them, because the man did not understand the subject and was too naive ${ }^{13}$.

However, his attempt to push the "bad" cattle onto Mr. Thobias did not seem to have gotten very far. He starts the next letter lamenting the business with Mr. Thobias and the difficulty of finding "acomplices": I think it difficult to do business with Mr. Thobias now because he is with his sights set very high and more or less did not buy cattle and after this, there wasn't a devil that worked in this farse ${ }^{14}$.

It is also curious to note the discursive strategies by which one defines "good" zebu cattle. The racial criteria from Brazil were not well established, though some of the characterisits were being defined by the first $19^{\text {th }}$ century importers. The importers from the Mineiro Triangle, breeders and traders, were also empirically "racializing" the zebu, studying and defining the characteristics which most belonged to them and distinguishing the "better" criteria.

12. Letter sent from Bombay, to João Carlos Salgado, on the $26^{\text {th }}$ of June, 1914, p. 5.

13. Letter of the 29th of June, from João Martins Borges to João Carlos Salgado, p. 6; letter of the $2^{\text {nd }}$ of July, 1914, id., p. 10.

14. Letter without a date and without a destination, p. 9. In the evaluation of the transcriber, it is the same destination, his partner, João Carlos Salgado, and the date would be somewhere between the $30^{\text {th }}$ of June to $2^{\text {nd }}$ of July, 1914, given that it is in a chronologically ordered copier. 
It is worth noting that in India, the division of bovine races was done according to region, and the initiatives of undertaking the selection of cattle were incipient and new, with the creation of the Charoddi farm, which fulfilled this function, starting from $1899^{15}$. The breadth of the territory and the centuries old distribution of herds by region, imposed a natural separation of pastures, further defined by the choice by each family of the profile of their animals. The size of the breeding area meant that there were no selection pressures, that is, a factor coming from the external and natural medium, which would drive the emergence of common genetic characteristics. To the contrary, in Europe, the diminished breeding terriotry imposed a homogeneity on the herd, and the practices on the part of the breeders to manipulate the genetics of the animals.

It is in this environment that João Martins Borges needed to create his strategies to acquire the "best" animals. In a letter to José Caetano Borges, João affirms having made the acquaintance of a man by the name of Nariman (requesting discretion regarding this matter), and confronts his Brazilian partner, saying that together with Nariman it would be easier to take up to 200 head of cattle to Brazil and that he can be certain that there would be no village that wouldn't be searched in the whole of Guzerat. He continues, saying that he was in Hissar, in the state of Harvana, and that there, there is a lot of cattle of a good type, however, without sufficient ear ${ }^{16}$.

This question of the ear is fairly symptomatic of the randomness or arbitrariness of the genetic characteristics. The requirement for a big ear was defined as particular to the zebu races by the first Fluminense breeders, and became a requisite in orders made by the breeders to the importing firms. However, as is obvious, this in no way influenced the quantity of meat or milk or force of traction produced by the animal.

In another letter from João addressed to his older brother Adolpho Martins Borges, from the Nhonhô class, he gives little practical news about the business and speaks more of his perceptions and feelings, of the difficulties with the voyage, to a certain extent even warning his brother, who seemes to have considered the possiblity of going to India. $\mathrm{He}$ confides: Purchasing cattle here is difficult, not that there is no good cattle, but it is that there,

15. For this assertion to be complete it would require a more profound analysis of the final projects to this end, realized by the English or other interested agents would be required, but to the point where we have researched, no other references of this type were encountered. It is a movement, in this manner, owing precisely to Brazilian interests.

16. Letter sent from Ahmedabad, to José Caetano Borges, on the $1^{\text {st }}$ or $3^{\text {rd }}$ of August, 1916, p. 50. 
they do not want good cattle, they only want deformed cattle, because an ear of $0.40 \mathrm{~m}$ is simply a deformity, a monstrosity ${ }^{17}$.

In this excerpt, we note that the racial characteristics considered good by breeders and which shaped the imagination regarding Indian cattle did not coincide with those adopted in India itself. It was, therfore, necessary to adapt discourses and be convincing via other racial advantages, creating a market demand, which would correspond to the offer of animals effectively available in India for these trader farmers. A change of the genetic and zoological paradigms related to zebu quickly became necessary. Even better was to breed the zebu races on Brazilian soil, as was done over the following decades, selecting nelore, gir, guzerá, brahman, and even breeding an Indo-Brazilian type, the indubrasil, or the induberaba, as it was initially called. This effort to breed/research zebu races in Brazil transformed the country into the American cradle of the Indian races.

Regarding the second reason for the secrecy of the negotiations, the monopolization of Indian contacts, we can cite an excerpt from a letter from João Martins Borges written on the second voyage to India, in 1916. There he explained to his partner João Caetano Borges that he would not send ahead news about his departure for Brazil to try to maintain information about the port where he had embarked and the routes by which he had passed secret because:

I risked my life too much to now exchange it for nothing, give information to whomsoever had not gone through any danger, come and make use of what I could tell [...] It is true that, as with me, any other could do it, I'm no better than anyone, but let them come, that they may risk their lives if they want to know something ${ }^{18}$.

The motivation is just and explicit: absolutely keep secret regarding my movements here, about steamers, because without competition I will obtain very cheap freight, João Martins Borges woudld say in a message to his partner José Caetano Borges in 1916, when he tried to return from India still taking the first load of animals which had been impossible two years earlier ${ }^{19}$. He continues in another letter:

I ask that you not say the least word to anybody about my movements here. Nobody should know that I was in Calcutta. Not having the slightest competition, and because of this, nobody writing to this city asking for information regarding steam

17. Letter sent from Ahmedabad, to Adolpho Martins Borges, on the $4^{\text {th }}$ of August, 1916. p. 52.

18. Letter sent from Calcutta, to José Caetano Borges, on the $5^{\text {th }}$ of July, 1916, p. 35.

19. Letter sent from Calcutta, to José Caetano Borges, on the $24^{\text {th }}$ of July, 1916, p. 43. 
ships, I am certain that I will find transportation for a picayune and will gain the voyage much more advantageously. Keep absolutely, absolutely secret what I am writing; not even to the most intimate should you say the least word, because many people there are waiting for news from me to come ${ }^{20}$.

He was already running out of time. The competion was becoming increasingly less trustworthy, given that João Martins went to India without any subsidy from the Brazilian government, at least officially, while others were already bringing cattle from Europe with incomparable facilities. Even with this being the case, the years between 1913 and 1921 were described as the peak of the importation cycle, when around 4,100 zebu bulls and females entered Brazil from numerous voyages (Lopes \& Rezende, 2001: 35). To achieve such success, beyond maintaining secrecy, it was necessary to undertake a certain level of espionage, as is clear in this message to his local agent and partner Nariman: send some of your men to Deesa to see if the parse Framroz is not gathering cattle for business in Brazil. I believe that he has arranged some calves for Armel ${ }^{21}$ referring to Armel Miranda, another trading farmer from Uberaba who also made three voayages to India in search of cattle and who at another time, was also the partner of João Martins Borges.

However, while there were no subsidies for João Borges' business, we cannot say that he did not politically and indirectly benefit from proximity with public office to achieve success with his business. In 1917 with the third voyage to the Asiatic continent, João Martins Borges referred in a postscript in a letter to the consul Joakim Nahapiet, to news taken from a newspaper that speaks about the steam ship Taubaté which came to Brasil from Calcutta, bringing a cargo of coffee and taking back jute for a Brazilian firm: Given that your Ex. is still not aware of the arrival of this ship, this means that the company, which imports jute is negotiating through another firm in Calcutta, in such a manner that your Ex. could take measures to gain the order for himself ${ }^{22}$.

The suggestion by João Martins Borges is clearly partial: gaining the order for himself, Nahapiet would certainly give him the best space on the ship to transport his cattle to Brazil. This observation indicates how much Nahapiet used his function as honorary consul to facilitate his jute business, and, by extension, the degree to which João Martins Borges would also benefit.

20. Letter sent from Ahmedabad, to Joaquim Martins Borges, on the $2^{\text {nd }}$ of August, 1916, p. 48.

21. Letter sent from Bombay, to Nariman, on the $9^{\text {th }}$ of August, 1916, p. 54. According to the transcriber, Ida Aranha Borges, parses are ancient Persian Zoastrians who, to escape Muslim persecution, emigrated and established themselves in India.

22. Letter sent to Ahmedabad, to Joakin Nahapiet, on the $19^{\text {th }}$ of December, 1917, p. 99. 
Other news that he gave to Nahapiet was about the help offered by the Brazilian government to another importer of zebu cattle, Militino Pinto Carvalho, which greatly displeased him. João says in the letter that, the minister of Brazilian agriculture authorized the Legation of the Brazilian Treasury, in London, to pay him the value of 3,996 pounds, which your Ex. should keep to deliver to Mr. Militino Pinto Carvalho, at the time of his being able to present to you documents and certification referent to the exportation of 111 head of cattle to Brazil23.

He also added for the consul, that Mr. Militino was at that moment in Japan trying to find a steamer for his cattle, which meant that he still did not know that the government would assist him. In the following, the tone of the letter becomes more serious when João begins to reveal the network of deception:

This cattle is not, in anyway, for distribution amongst breeders by decision of the government, as is said in the note, but rather for my nephew, Mr. Manoel Borges. They are saying this only to receive finnancial help from the government, because legally no assistance could be received from the ministry, if not that the cattle was to be distributed. There is much deception in all of this ${ }^{24}$.

Regarding this news retold by João Martins Borges, it implies a confirmation of the idea that it is impossible to speak of an absence of government assistance for zebu cattle in Brazil, not even in 1917, when the minister of agriculture was not a "zebu enthusiast".

There were therefore, interest groups, solidarity networks and a specific manner of accessing the subsidy directly from the State in the middle of the intraoligarchical disputes. It was not surprising then, that João did not distance himself from participating in this game to obtain state assistance and subsidises. As he said in a second letter about the subject, this time to his partner in Brazil, João Caetano Borges:

Through letters and newspapers from there, I know that Mr. Manoel Borges, Geraldino and others managed to find government assistance for the importation of cattle. I hope that you have also done everything possible for us to obtain this favour. I will bring the necessary documents, but the requirement for the Ministry and its deferral need to be ready beforehand, long beforehand. Do everything that is possible. Arrange this with Theófilo de Azevedo. The concession made to Manoel Borges is the supra sumo of dishonesty. The government could very well concede the

23. $I d$.

24. Id. 
assistance, but never send the money here as it did, before the animals were to be imported. It is against the law. The assistance, in itself, can only be made after the animals were examined and disembarked in the country. If this cattle died on the way? The assistance will have been given because 3,996 pounds (80,000\$000) would be paid here by the government. It is ridiculous. ${ }^{25}$.

It is not surprising that João Martins Borges had denounced as "dishonesty" the use of government assistance to acquire cattle for resale to particulars and the failure to satisfy the law in obtaining the assistance prior to the cattle being disembarked in Brazil. This was exactly the situation in which João found himself, and he requested that his partner make every effort to try to achieve exactly this for his own business.

It is in that way that we can explain the strategy of secrecy. In this specific case, secrecy regarding his movements was an attempt to compensate for the advantages, which placed his competitor as a market leader. In the same letter, he said to Caetano Borges that he would block Militino from overtaking him by securing transportation, saying that he was a government representative and offering bigger payments [...] for considering such action highly undignified. Each one serves himself and should not disadvantage the other ${ }^{26}$.

If the first voyage was to a large extent a failure due to the war having broken out, blocking the finalization of negotiations and the arrival of the cattle in Brazil, from this third voyage João did not even manage to return alive to Brazil. The second voyage in 1916 however, was certainly a successful endevour. As he himself described, in a letter to Nariman, when he arrived: They said that the cattle was the best herd of Indian cattle ever seen in Uber$a b a$. There was enormous enthusiasm. Half an hour after my arrival, I sold 46 head of cattle for $134.500 \$ 000$ (134 thousand and 500 rupes). Never before had a lot of cattle been sold so quickly achieving such a price ${ }^{27}$.

In view of the excellent business, João requested that Nariman buy and send 50 more head of cattle, because: It was a very good sale, considering the price and the speed with which the payment was made. The cows were highly praised, but the bulls, as the letter says, though they were very good, were not as good as the breeders here were used to imagining. Pay much attention to the bulls, if you have bought any ${ }^{28}$.

25. Letter sent from Ahmedabad, to José Caetano Borges, on the $22^{\text {nd }}$ of December, 1917, p. 100.

26. Id.

27. Letter sent from Conquista-MG, to Nariman, on the $30^{\text {th }}$ of December, 1916, p. 82.

28. Letter sent from Conquista-MG, to Nariman, on the $3^{\text {rd }}$ of March, 1917, p. 84 . 
The commentary that one could not find as many good bulls as females or hefers was common throughout the letters, certainly owing to the phynotypical requirements commonly made by Brazilian breeders, which did not correspond to animals that were to be found in India. This, evidently, placed the business still further at risk and it was best to avoid the bulls, so that there was no waste in resale in Brazil.

Regardless of the heroic fame that the character João Martins Borges received, and the significance that he still has today amongst cattle breeders of diverse races of zebu origin, the feeling of desperation and abandonment that characterized the undertaking of his business in India during all three voyages is notable. Even with the possibility of support from the Brazilian government, and with the apparent availability of the Brazilian and English departments, João seems to have been the only one not to have directly made use of these means. While the general context seems to have been one of a "peak" of Indian cattle importations into Brazil, one can say that it was still a difficult period in relations between these cattle farming groups in the Mineiro Triangle and republican politics ${ }^{29}$.

Contradictorily, this "isolation" was fundamental in the construction of a political and social distinction of the cattle breeders of the Mineiro Triangle, and would have been exactly what gave João Martins Borges his heroic fame.

We speak of the apparent availability of the Brazilin and British departments because they were linked to ambiguous episodes in terms of this assistance. Apparently, the English were in no way opposed to Indian cattle, but when they could make problems using their colonial authority, they did. When João Martins Borges tried to finalize his third and last voyage, already with almost 200 head of cattle bought, merely awaiting the opportunity to transport them to Brazil, he wrote to José Caetano Borges complaining of the difficulties in obtaining licences to take the cattle from Sanand to Calcutta, given that the railways are under military control. In the same letter, he also asks his partner to obtain from the British government by way of the Brazilian government, permission for the transportation of our cattle on board the Thongwa, which should depart any day now for Santos. This steamer would take jute to the Companhia Paulista de Aniagens and would be a great solution for the transportation of the animals, if not for the fact that João Martins Borges was telegraphing "insistently" for the Brazilian Embassy in London, and not obtaining a response $\mathrm{e}^{30}$. In the end, his hopes were dashed. The steamer Thongwa was lost

29. During the period of João Martins Borges' voyage, the agricultural pastures were occupied by Pandiá Calógeras and João Gonçalves Pereira Lima, who did not seem to be especially connected with Indian cattle, regardless of the evident incentives to Mr. Militino, described above.

30. Letter sent from Calcutta, to José Caetano Borges, on the $12^{\text {th }}$ of March, 1918, p. 113. 
due to the interpretation that they made, in London, of my telegrams, and to the lack of urgency with which they responded ${ }^{31}$.

This seems to have been proof of a boycot, or at the very least, indisposition on the part of the British for the business of shipping cattle from India to Brazil. This attitude could be explained, partly, by the fact that the main races imported until then to improve the Brazilian and platine herds were English. That is to say, Britain had a historical interest in monopolizing the market of breeding cattle. The capital invested in the freezers, which began to spread throughout Brazil, permitting both meat exportation and meeting the needs of a domestic market in clear expansion, and as a result, the implantation of modern, industrialized breeding, which was also British ${ }^{32}$. The meat, and the breeding stock markets were therefore, strongly linked, and a crisis in one affected the other, to the extent that these matters were being discussed in diplomatic relations between Brazil and England. This may have influenced the indisposition to help the trading farmers from the Mineiro Triangle.

The failure of João Martins Borges' first voyage and the difficulties for the return of the second, were fundamentally due to difficulties during the middle of the War, to obtain permission and authorization for transport. They were hampered at every step along the way, on one side by the Brazilian government, on the other by the British government; the Brazilian consulate in India, and the Brazilian Embassy in London. The failure of the first voyage even created a fairly substantial debt at the Charoddi farm, where the Uberabense trader had to leave the animals. This debt was in part compensated for by the success of the second voyage. However, from the third, undertaken in 1917, João Martins Borges would not escape unscathed, as has been previously observed. Our illustrious visionary died in the country of mystery and magic realism, with his sacred cows and mythological oxes, on the look out for a Catholic priest, a youth from the Brazilian Consulate with a couple of Hindu friends (Nabut, 1975: 130-31).

31. Letter sent from Calcutta, to José Caetano Borges, on the $29^{\text {th }}$ of March, 1918, p. 122. According to Ida Aranha, this letter was not sent on given that she encountered the original together with the copy in the copyist's notebook.

32. Regarding the growth of the internal market for food supplies that was accentuated by the process of urbanization, see especially LINHARES and SILVA (1979). 


\subsection{The return to Brazil}

The aspects reported here of the voyages of João Martins Borges allows us to argue that the technological growth (in the case of the bovine racial standardization using zebu races), which transformed Brazilian cattle breeding into industrialized production had broader motivations than immediate economic gains. The farmers who went to India were driven by diverse motivations that could not be reduced to an increase in economic productivity and the attempt to put bovine meat on the agenda of products destined for agricultural exportation within the neocolonial model (Chasteen, 2001). This was the only convincing discourse, which they could propose at the time. In truth, these were political interests precipitately related to the strengthening of personal prestige and the construction of a class attribute as cattle grazers, or further still as rural bourgeoisie and not simply animal breeders or landowners. This distinction was fundamental in a context of interoligarchical disputes in the Republican State then in formation.

Regarding this question, Sonia Mendonça points out the action of rural elites not connected to coffee cultivation in the first decade of the Republic, be it due to their producing for the domestic food market, or due to their production for exportation being small in comparison to the general context of exports, as was the case with cattle grazing producers of meat. The author brings a significant contribution, when she identifies the Ministry of Agriculture, Commerce and Industry, founded in 1906 and consolidated in 1909, as the most important instance for the reception and articulation of the demands of the non hegemonic elites, and, therefore, as the official site of disputes for the rural elites, within which there was a governmentalized institutionalization of the interests of non hegemonic factions of the dominant agrarian class (Mendonça, 1997: 17). However, for the farmers of the Mineiro Triangle, as well as for those who made up the firm Borges \& Brothers, who did not even manage to access the Ministry of Agriculture, the strategy to obtain distinction amongst their contemporaries, economic advantages and influence in Republican politics began to rely on innovation, and risky investments in an effort in a "circle of friends" that characterized the "vanguard" in the reading that Carmen Sesto makes of the concept of Schumpeter referred to at the start of this article. With this, it is possible to admit the idea that there was also in Brazil, the formation of a cattle grazing vanguard that broke with the hegemonic explanation that the rural bourgeoisie only relied on "natural advantages" and on exploitation as a strategy to accumulate capital.

Considering the more concrete impacts that zebu generated in Brazil, it is possible to infer that as well as meeting international demands, and, at least partially, meat and dairy demands of domestic markets that were expanding with urbanization, it also satisfied a conservationist discourse. This had emerged already at the end of the 1920s and gained 
force with Getúlio Vargas and the creation of the first Forestry Code in 1934. Though it appears contradictory, the environmental impact of the removal of forest cover that agriculture generated was minimized not only due to the discourse regarding the hardiness of the zebu, which supposedly meant less environmental impact, but also with nationalism as a management criteria for natural resources. From this perspective, the country should maintain itself essentially focused on rural production, also given that the frontiers were open, and Brazil needed to advance the civilization of the sertões in an industrious and rational manner. In other words, zebu breeders created a self-image as environmental patriots who used natural resources with the aim of the economic modernization of Brazil. This image is maintained up until today amongst the members of the rural classes as a characteristic strategically used to reaffirm their "distinction" and class position.

In 1975, the urn that held the mortal remains of João Martins Borges in Calcutta, was brought to Brazil at the request of the Brazilian Association of Zebu Breeders (BAZB), in a transfer facilitated by the Ministry of Exterior Relations. The president of the BAZB at the time, Arnaldo Rosa Prata, took on the task of replacing the original wooden urn with a distinguished silver one, making a speech in homage to the youth who with each passing day after his death became more of a hero. The new tomb in Uberaba received an inscription with excerpts from Arnaldo Prata's speech: that this homage serves to lessen the pain of those who loved him and lost him, such that history could have him ${ }^{33}$. In this city, his story will be better venerated, retold, and eternalized as a martyr to national cattle farming, or better, as an "idol of origins" of Brazilian rural entrepreneurs.

\section{ACKNOWLEDGEMENTS}

We would like to thank Josep Pujol Andreu and Amelia Polónia, the convenors of one of the panels at the International Conference of Sociedade de Estudios de Historia Agraia - 2016, for the effort they put into the publication of this paper. Our thanks also go to Prof. Dra. Marcia Motta, professor at the Universidade Federal Fluminense for her supervision of the doctoral thesis on which this article is based, and particularly Thomas Dwer, professor at the Universidade Estadual de Campinas, who supervised the post doctoral research from which some of the data used in this version was obtained. We would also to thank Phillip Villani, for his clear translation of the paper, and the reviewers and editors of Historia Agraria.

33. Uncatalogued documents. The collection of the Zebu Museum, arch. 001, draw 002, file 054.

Historia Agraria, 75 • Agosto $2018 \cdot$ pp. II $5^{-1} 3^{8}$ 


\section{REFERENCES}

Chasteen, J. C. (2001). Neocolonialismo. In América Latina: Uma História de Sangue e Fogo (pp. 149-75). Rio de Janeiro: Campus.

Crosby, A. (1993). Imperialismo ecológico: A expansão biológica da Europa 900-1900. São Paulo: Companhia das Letras.

Dean, W. (1996). A ferro e fogo: A história e a devastação da Mata Atlântica brasileira. São Paulo: Companhia das Letras.

Fragoso, J. L. R. (1986). A roça e as propostas de modernização na agricultura fluminense do século XIX: O caso do sistema agrário escravista-exportador em Paraíba do Sul. Revista Brasileira de História, 6 (12), 125-50.

LINHARES, M.Y. L. \& SiLVA, F. C.T. DA (1979). História politica do abastecimento (19181974). Brasília: BINAGRI.

Loво, E. M. L. (1980). História político-administrativa da agricultura brasileira (18081889). Brasília: Ministério da Agricultura.

Lopes, M. A. B. \& REZENDE, E. M. M. DE (2001). ABCZ: História e Histórias. São Paulo: Comdesenho.

MEDRAdo, J. (2013). Do pastoreio à pecuária: A invenção da modernização rural nos sertões do Brasil Central. PhD thesis. Rio de Janeiro: Universidade Federal Fluminense.

MeIRELles, C. S. (1944). Bovinos das raças indianas. São Paulo: Federação Paulista de Criadores de Bovinos.

Mendonça, S. R. (1997). O ruralismo brasileiro (1888-1931). São Paulo: Hucitec.

NABUT, J. A. (1975). Coisas que me contaram, crônicas que escrevi. Uberaba:Vitória.

SESTO, C. (2000). Tecnología pecuária y periodización: El refinamiento del vacuno en la provincia de Buenos Aires entre 1856 y 1900: Un intento de re-periodizar, incorporando como factor central de analisis el empleo de una tecnología de alta productividad. Redes, 16 (7).

Silveira, A. DA (1917). Floresta e pecuária. Belo Horizonte: Imprensa oficial do Estado de Minas Gerais. 